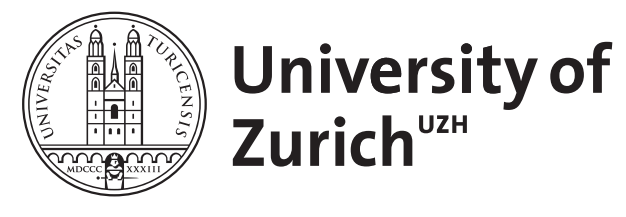

\title{
Fighting Political Terrorism by Refusing Recognition
}

\author{
Frey, Bruno S
}

\begin{abstract}
Terrorists act rationally; one of their dominating goals is to attract public attention to their cause. As a consequence, the authorities should refrain from attributing a particular terrorist incident to any one group. They should stress that many different actors must be considered as the possible perpetrators. Such an information policy sharply reduces terrorists'rewards. The terrorists are therefore likely to cut down on such activities or must undertake riskier acts, which increase their chance of being caught. The approach suggested is complementary to the policies currently in use; it does not make police measures unnecessary. The strategy is, however, active while the traditional approaches are passive responses to terrorist activities. In contrast to other anti-terrrorist measures, it does not violate human liberties, civil rights or the freedom of the press
\end{abstract}

DOI: https://doi.org/10.1017/s0143814x00005225

Posted at the Zurich Open Repository and Archive, University of Zurich ZORA URL: https://doi.org/10.5167/uzh-154566

Journal Article

Published Version

Originally published at:

Frey, Bruno S (1987). Fighting Political Terrorism by Refusing Recognition. Journal of Public Policy, $7(02): 179$.

DOI: https://doi.org/10.1017/s0143814x00005225 


\title{
Fighting Political Terrorism by Refusing Recognition*
}

\author{
BRUNO S. FREY Economics, University of Zurich
}

\begin{abstract}
Terrorists act rationally; one of their dominating goals is to attract public attention to their cause. As a consequence, the authorities should refrain from attributing a particular terrorist incident to any one group. They should stress that many different actors must be considered as the possible perpetrators. Such an information policy sharply reduces terrorists' rewards. The terrorists are therefore likely to cut down on such activities or must undertake riskier acts, which increase their chance of being caught. The approach suggested is complementary to the policies currently in use; it does not make police measures unnecessary. The strategy is, however, active while the traditional approaches are passive responses to terrorist activities. In contrast to other anti-terrrorist measures, it does not violate human liberties, civil rights or the freedom of the press.
\end{abstract}

This paper presents a new element in the strategy of fighting terrorism. It is assumed that terrorists act rationally and that their main goal is to attract public attention to their cause. A policy of information by the authorities which refrains from making any particular group responsible for a certain terrorist act and explicity takes all the possible actors into consideration therefore reduces the terrorists' rewards. They either have to switch to more overt activities which increases the risk of being caught or they desist from further terrorism. This strategy, being active in opposition to the traditional methods, forces the terrorists to react.

\footnotetext{
* I am grateful for helpful discussions to James M. Buchanan, José Antonio Blanco, Reiner Eichenberger, Klaus Foppa, Francesco Forte, Beat Gygi, Douglas Hibbs, Peter Graf Kielmannsegg, Cornelia Klinger, Serge Kolm, Barbara Krug, Franz Ritzmann, Hannelore WeckHannemann and Charles Wolf. The idea was presented at the Study Group on Economics, Psychology and Sociology (OEPSAG), at the Internal Seminar on Economic Policy at the Institute for Empirical Economic Research, and at the Departmental Research Seminar.
} 


\section{Helplessness}

Over the last dozen years political terrorism has become more important than ever. The incidents range from kidnapping individuals and hijacking collective means of transportation (planes, ships and even trains) to bombings. Kidnapping of prominent individuals such as the president of the German Employers' Association Hanns Martin Schleyer in 1977 or of the Italian ex prime minister Aldo Moro in 1978 have resulted in deadly outcomes, and many innocent by-standers have been killed in other acts of terrorism. Accordingly, terrorist acts have received great attention in the media: there is 'virtually a 100 per cent probability of achieving worldwide or at least national publicity' (Jenkins and Ronfeldt 1977, p. 1). The estimated world-wide media audience of a significant terrorist act is 500,000,000, i.e. terrorists can count on 'a public opinion prize probably unmatched in history' (Watson 1976, p. 195). Signs of hysteria have appeared. The fight against political terrorism has had considerable repercussions on most societies: new police groups have been established, and new techniques of investigation and search have been introduced. As a result the human rights and civil liberties have been curtailed, and in times of acute terror have been openly violated.'

The reaction of the authorities to this wave of political terrorism can be described as inadequate, and even helpless (see e.g. Crelinsten and Szabo I 980 , pp. $8 \mathrm{I}-3$ ). The fact that not more people have been killed seems to be more the result of luck than of good management of the crises by the authorities. The authorities have tended to resort to illegal or at least illegitimate means to fight terrorism. Morever, they have allowed the terrorists and their causes to get prominent attention (and thus have helped to achieve one of the main goals of political terrorists), and have even gone so far as to negotiate with the terrorists on an equal footing, violating the constitutional principle that the state has to maintain the monopoly of force in society.

This paper suggests a new strategy to deal with political terrorism which avoids some of the major disadvantages of current policies. In particular, the civil liberties of the population remain intact while terrorist acts may be expected to decrease significantly. Terrorists' behaviour and the workings of the new strategy for fighting them are discussed in section II. Possible objections are dealt with in section III. The following section compares the new strategy to the currently used one, and section $V$ offers concluding remarks. 


\section{The stategy outlined}

\section{The behaviour of terrorists}

Terrorists do not act without purpose, rather they are goal oriented actors (Stohl I 979, pp. 6-7). Political terrorists want to draw public attention to their cause, and/or want to achieve specific political demands (such as the release of imprisoned members of their group). Media recognition is absolutely crucial; the success of a terrorist act depends mainly on the media coverage it enjoys: 'Terrorist action is nothing, publicity is everything' (Laqueur 1978, p. 225; 1977, p. 105). A 'vital factor [for the proliferation of international terrorism] is the impact of modern communications media. Terrorists are today given free world-wide publicity' (Wilkinson 1974, p. I 24). ${ }^{2}$ One may even speak of an 'implicit theatrical nature of terrorism' (Corsi $198 \mathrm{I}$, p. 48) in which 'the mass media take a vital role' (Crelinsten and Szabo 1980, p. 89).

Terrorists act to achieve their goals by considering the benefits and costs associated with alternative actions. When there are two actions available (say kidnapping a prominent politician or throwing a bomb indiscriminately in a gathering of people) they will choose the one which yields higher benefits in terms of achieving the goals, or which entails lower costs in terms of material needed and risk of being captured, wounded or killed.

In this (limited) sense terrorists may be taken to act rationally. ${ }^{3}$ Terrorists are neither madman ${ }^{4}$ nor is their behaviour random, rather it is systematic and, in principle, predictable. This view of terrorists is in line with previous analyses (see in particular Landes 1978; Sandler, Tschirhart and Cauley 1983; Kirk 1983; Atkinson, Sandler and Tschirhart 1987; Sandler and Scott 1987). It accords well with reality: terrorists are known for careful preparations of their acts, gathering information and meticulously planning the procedure. It has been shown in careful investigations (Mickolus 1980, Gurr 1979) that political terrorists systematically react to changes in factors such as risk and the probability of a clash with the authorities. Terrorist activities with high risk like hijacking and hostage-taking occur the least often while activities with low risk like bombings and assassinations occur the most often.

\section{Refusing recognition}

Based on this view of terrorists' behaviour, they can be discouraged from acting by reducing their utility of goal attainment. The authorities in charge must in particular ascertain that a particular group of terrorists do not receive the credit and therewith the public attention for having 
committed a terrorist act. The authorities must see to it that the terrorist act is not attributed to those people who have undertaken it and who have made the respective effort and taken the risk. There are two strategies for refusing to attribute a terrorist act to a particular group:

( 1 ) All information on terrorist activities is suppressed; the authorities behave and talk as if no such terrorist act has happened. ${ }^{5}$ In an open and free society it is extremely difficult, if not impossible, to withhold information in which the media is highly interested. In effect, the freedom of the press is seriously limited either by 'voluntary' agreement or by law. As the foreign press and news media are not bound by such agreements and laws, it is, at least in a democracy, most likely that the news leaks out. The terrorists can easily inform foreign news agencies which, due to the competitive pressure to provide interesting news, will normally be ready to inform the international public about the terrorist act. This first strategy must therefore be rejected as being ineffective and incompatible with democracy.

(2) The information available to the public may be 'thinned'. This can be done by making it known that several terrorist groups may be responsible for a particular terrorist act. The authorities have to reveal that they never know with certainty who has committed a terrrorist act. Even when it seems obvious what terrorist group is involved, the police can never be sure because it may be a politically opposed group who has committed the act in order to incriminate the more 'obvious' groups, and invite police action against the latter. Rather the authorities have various hypotheses to which they attach various degrees of belief. They must communicate this probability distribution of possible actors to the public. They have to refrain from attributing a terrorist act to any particular group as long as the truth is not established. In a lawful country, this is the privilege of the courts, but not of the police.

Usually, there are several groups claiming to have committed a particular terrorist act. There are cases in which the media have attributed it to some innocent terrorist group, as it later turned out (Laqueur 1977, p. 106). The authorities have to stress that any one of them may be the responsible one. As a consequence, the various media draw the public's attention to many different, and possibly conflicting, political goals. In the unlikely case that only one group claims to have committed the terrorist act, the authorities responsible have to point out that such a claim is not substantiated and that experience teaches that several different groups may have undertaken the act, but choose to be silent. They may point out that many cases are known where groups have claimed to have committed particular terrorist acts in order to draw the attention of the mass media to themselves. Thus even in the case of only one claimant, those having committed the act receive only part of the publicity involved, and possibly a small part only. 


\section{Effects}

The information strategy outlined has systematic and hence predictable effects on the behaviour of both terrorists and responsible authorities. The benefits derived from having committed a terrorist act decreases for the group having undertaken it because the group does not reap the public attention hoped for. The political goals it wants to publicise are not propagated as much as they desire. This reduction in publicity makes the terrorist act (to a certain degree) senseless: 'all modern terrorist movements require publicity' (Laqueur I977, p. I o6).$^{6}$ Terrorists who are ready to take the high risk - and even the risk of death - in order to put forth their political beliefs feel deeply dissatisfied. The frustration is intensified by the feeling that other political groups who were not as 'brave' as to have run the risk to undertake terrorist acts are free riders and reap benefits in terms of increased publicity free of charge. This frustration is often intense because terrorist groups tend to be in a state of strong competition, even when they have similar political beliefs. None of them is ready to accept that it undertakes dangerous actions but that another group receives the credit for it. Most terrorist groups would prefer that no one is credited than that the publicity is shared by a competing group. The authorities in charge fighting terrorism may exploit this competition among terrorist groups by pointing out to the media that among the likely authors of a particular terrorist act there may be terrorist groups known to be in competition with each other.

The authorities' strategy resulting in a strong decrease in the rewards for terrorist acts, the terrorist groups concerned may react in three possible ways:

(I) The terrorists make an effort to establish the authorship in a terrorist act by providing appropriate 'proofs'. This can, for instance, be done by providing photographs (e.g. showing a hostage with a newspaper of a particular date as was done in the case of the kidnapping of Schleyer in Germany). The authorities, knowing well that such photographs are easy to fake, will have to point out that this is no adequate 'proof', and in many instances they can indicate that similar 'proofs' have been presented by other claimants. While the initial attempt to establish authorship undoubtedly receives public attention, this will also be true for the possible counter-evidence provided by the authorities. Another possibility for establishing a 'proof' is by getting into direct contact with journalists. Such action involves considerable risks because the terrorists have to partially come into the open which renders them an easier target for normal police activity. The terrorists can, for example, not exclude that one of the journalists they make contact with informs the police about a planned meeting. The authorities have, moreover, counter-strategies available: they can reveal what evidence they possess, suggesting that a 
competing terrorist group may well have committed the terrorist act concerned.

(2) The terrorists switch to a more overt type of terrorist activity in order to make sure that its authorship is established beyond doubt. Such behaviour increases the risk of being caught by the police.

(3) The terrorists desist from further terrorist activity because it does not pay and switch to a non-violent way of publicising their demands.

It may be noted that each one of the three types of reaction result in a decrease of terrorism either because the terrorists choose to so act or because the police get a better position to detect and overwhelm them.

The strategy here suggested also leads to a change in the behaviour of the authorities. Most importantly, as long as the authorship of a terrorist act is not clearly established, they do not have to yield to the demands made. As long as they can argue that they do not know which of the conflicting demands should be fulfilled, they do not even have to reject the demands. In the case of kidnappings this means that there is little risk that the terrorists respond by killing the hostages as they would not gain anything by doing so. Thus, no ransom money has to be paid. If political terrorists demand that some announcement is read on TV or published in newspapers, this may even be granted, provided several announcements by different terrorist groups are arranged, a fact which strongly reduces the effect of any particular announcement.

To summarise, the following results may be expected from applying the strategy suggested: the authorities take the initiative by actively taking steps to reduce the attention the terrorists receive from the public. The terrorists become frustrated by the missing reward from the risky terrorist acts, desist from further activities, or increasingly expose themselves to ordinary counter-terrorists methods by the police. The amount of terrorism will decrease; the dissatisfaction with existing political and social conditions will be expressed in different, less violent ways. ${ }^{7}$

\section{Possible objections}

The strategy of refusing recognition by supplying more information than desired by the terrorists may be objected to on various grounds.

\section{Cost of non-commitment}

The public expects, and has a right, to be truthfully informed by the authorities on public affairs, including terrorism. The strategy of refusing recognition by leaving all possibilities open until truth is established in court may possibly appear to the citizens as if information were withheld, because not one particular terrorist group is presented as the author of a 
particular act. In order to overcome this (mistaken) feeling, the authorities must make it clear that there are by necessity always a number of different suspects and that in a democratic society it is the courts' sole authority to establish who is guilty. The fact that there are more or less likely authors does not allow concentration on only one of them.

\section{Limited applicability}

The strategy based on refusing recognition is relevant for clandestine terrorist act such as kidnapping with an unknown hiding place and bombings. This is an advantage rather than a disadvantage because 'most expert knowledge to date deals with hostage situations. in which the site of the hostage is known. Where the site is unknown, operational strategies and tactics are much less clear-cut and well-developed' (Crelinsten and Szabo 1980, p. 81). The strategy is not so well applicable for overt kidnapping where the hostages are kept at a publicity known place. The authorities can still argue that the kidnappers, say of a plane or ship, are not fully identified, and that there are competing claims on who they really are and what cause they really champion. However, the possibility of using such a strategy is more limited than in the case of clandestine terrorist activities. The strategy suggested is complementary, and not substitutive, to ordinary police activities. Open terrorist actions can be fought by classical police methods such as attacks by appropriately trained and armed forces.

The strategy is also inapplicable if terrorists' behaviour were solely motivated by creating chaos. In that case terrorists derive no utility if their movement and their political goals are identified. The literature (see footnote I) does not indicate, however, that such a utility function is widespread, if it exists at all.

\section{Unwillingness to use the strategy}

The politicians and the police chiefs responsible may be reluctant to apply the strategy of refusing recognition because it gives the impression to the public that the authorities are incompetent as they do not appear to know which group is responsible for the terrorist act concerned. The politicians and public authorities in charge prefer to state that they are well informed and that they will soon be able to capture the terrorists, even if this is more wishful thinking than reality. The strategy has, moreover, the disadvantage that the decline in terrorism brought about by the choice of the terrorist groups is not directly attributed to the police and other public authorities. Both would, of course, prefer to be directly credited.

The small incentives for the official decision-makers to apply the 
strategy is a serious problem. A competent government may, however, be able to attribute the success of the anti-terrorist policy to their actions and particularly by pointing out its success. In times of crisis, which often obtains when terrorism mounts, the parties in a democracy tend to form an implicit or even explicit coalition with respect to anti-terror policy; the government is insulated during this period from usual party competition and can, if it desires, pursue the strategy suggested. The government can also show its determination to fight terrorism by pointing out its use of classical police methods.

It is, however, not necessary to rely only on the enlightened self-interest of the government. Laws prohibiting an unproven accusation of having committed a terrorist act may be introduced or strengthened, and it must apply also to the public authorities, including the police. As a result, the authorities would be more careful to attribute a terrorist act to a particular group but would be forced also to indicate other possible actors. The laws would firmly establish that only the courts may establish who is guilty. Once the courts have decided, the group actually having committed the crime gains the undivided publicity, but this is long after the terrorist act has taken place. In a world characterised by many news items and among them many atrocities, the amount of attention paid by the mass media and the public is considerably smaller than it would have been at the time of the terrorist act.

\section{Comparison to current anti-terrorist policy}

There are six major differences between the strategy of refusing recognition and the policy currently used:

(I) The strategy is active, the authorities force the terrorists to react. The currently used anti-terrorist policy is, on the other hand, reactive, the terrorists dictate the procedure and the terms under which the interaction takes place.

(2) The strategy refuses to give terrorists the rewards going with public attention. The current policy tends to publicise and officially acknowledge the existence of the terrorist group and therewith its cause.

(3) The strategy allows the authorities not to yield to the demands raised by the terrorists without running an increased risk. The current policy seeks a favourable outcome by negotiating about the terms of the demands with the terrorists on an equal level. The consequence tends to be that the terrorists commit further violence in order to ensure that their demands are met.

(4) The strategy lowers the rewards of terrorist actions which also reduces the incentives to terrorists for future terrorism. The current terrorist policy invites future terrorism in so far as it has met terrorist demands in the past. 
(5) The strategy does not touch the freedom of the press and of the other media. Current anti-terrorist policy is usually accompanied by a suppression or reduction of free reporting.

(6) The strategy does not infringe on human rights and civil liberties. The current anti-terrorist policy with its emphasis on heavy use of police power and on modern methods of investigation and surveillance is bound to reduce citizens' rights.

\section{Concluding remarks}

The discussion suggests that a fight of terrorism based on the refusal to acknowledge terrorists by oversupplying information may be a useful extension to existing policies. It has become clear that it is not alternative in the sense that it would make police action unnecessary. It is, however, a clear alternative with respect to how information is to be handled.

Anti-terror practitioners would have to find the exact ways to implement the new kind of information policy put forward theoretically. The strategy may be openly discussed, its effect does not depend on the fact that the opponents (the terrorists) do not know it. Rather it is one of the remarkable features that it is largely immune to counterstrategies.

\section{NOTES}

1. For a survey of forms and trends of present day terrorism see, among a large literature, e.g. Wilkinson 1987; Cordes et al. 1984; Mickolus 1980, 1982; Corsi 1981; Jenkins 1982; Midlarsky, Crenshaw and Yoshida Ig80; Alexander, Carlton and Wilkinson I979.

2. 'Modern terrorists . . . seck to use spectacular acts of terrorism as a dramatic and effective means of publicizing both their cause and the movement to specific governments and to world opinion' (Wilkinson 1977 , p. 111).

3. Under present conditions terrorism does not seem to be an unprofitable enterprise. For example, in the period 1968 to 1984 in which 549 hostage-taking events were counted, in 475 or $87 \%$ of the cases the mission was completed as planned, and in 147 cases $(27 \%)$ all of their demands were moreover met (Sandler and Scott 1987 ). For further figures concerning the success rates of various terrorist activities over the period 1968 to 1974 see Milbank (1976, p. 22).

4. According to Miller (1979) it is not true that terrorists are not concerned about their lives. Also captured terrorists have elaborate plans for escape. Stohl (1979, p. 5) writes of a 'myth, one that finds particularly warm reception in the American media and in governmental statements concerning terrorism, is that terrorists are mentally unbalanced . . . only madmen would resort to many of the actions that terrorists have undertaken. . . Rarely are actions of terrorists presented as part of an on-going political struggle, related to any particular goals, and rarely are these goals presented as reasonable or even meaningful'.

5. This is the typical response of Israel to PLO terror. It indicates a governmental unwillingness to reward terrorists for their actions or even to acknowledge their existence (Stohl 1979, p. 394).

6. The lack of publicity was the major reason why the guerrilla moved from the country to the cities during the 60 s. In a city, the terrorists can always count on the presence of journalists, TV cameras and a large crowd. This lesson was quickly learned by South American, Arabic and African guerrillas. As one Algerian guerrilla leader said: 'Is it better for our cause to kill ten of our enemies in a far away village without receiving attention, or to kill somebody in Algier where the American and European press reports the incidents the next day securing world wide attention?' (See Laqueur 1977, pp. 105/106). 
7. It has been shown (CIA $198 \mathrm{I}$ ) that measures taken in the past to increase the cost of types of terrorist activities have motivated terrorists to switch to less costly activities. As an increase in cost is equivalent to a decrease in benefits, this substitution effect has empirically been observed.

\section{REFERENCES}

Alexander, Y. (I 979) 'Terrorism and the Media: some Consideration'. In: Y. Alexander, Carlton, D. and Wilkinson, P. (eds.), Terrorism: Theory and Practice. Boulder, CO: Westview.

Atkinson, S. E., Sandler, T. and Tschirhart, J. (1987) 'Terrorism in a Bargaining Framework', Joumal of Law and Economics, vol. 30, forthcoming.

Cordes, Bonnie, et al. ( 1984 ) Trends in International Terrorism, 1982 and 1983. Santa Monica, CA: Rand.

Corsi, Jerome R. ( 1981 ) "Terrorism as "Desperate Game", Joumal of Conflict Resolution 25, March.

Crelinsten, Ronald and Szabo, Denis (1980), Hostage Taking. Lexington, MA: Lexington Books.

Gurr, T. R. (1979) 'Some Characteristics of Political Terrorism in the 196os'. In: Stohl, M. (ed.), The Politics of Terrorism. New York: Marcel Dekker.

Jenkins, Brian M. and Ronfeldt D. (1977) Numbered Lives: Some Statistical Observations from 77 International Hostage Episodes. Santa Monica: (P. 5905), Rand.

Jenkins, Brian M. (1982) Terrorism and Beyond: An International Conference on Terrorism and Low-Level Conflict. Santa Monica: Rand.

Kirk, R. M. ( 1983 ) 'Political Terrorism and the Size of Government: a Positive Institutional Analysis of Violent Political Activity', Public Choice 4o.

Landes, William M. ( 1978 ) 'An Economic Study of U.S. Aircraft Hijackings, I $96 \mathrm{I}-1976$ ', Joumal of Law and Economics, vol. 2 I, April.

Laqueur, Walter (ed.) (1977) Terrorismus. Kronberg/Ts.: Athenäum.

Laqueur, Walter ( $\left.197^{8}\right)$ Zeugnisse Politischer Gewalt, Dokumente zur Geschichte des Terrorismus. Kronberg/Ts.: Athenäum.

Mickolus, Edward F. (1980) Transnational Terrorism: A Chronology of Events, Ig68-1979. Westport, Conn.: Greenwood Press.

Mickolus, Edward F. (1982) International Terrorism Attributes of Terrorist Events, 1968-1977. Ann Arbor, Michigan: Inter-University Consortium for Political and Social Research.

Midlarsky, Manus J., Crenshaw, Martha and Yoshida, Fumihiko ( I980) 'Why Violence Spreads', International Studies Quarterly 24, March, I.

Mibank, David ( 1976 ) International and Transnational Terrorism: Diagnosis and Prognosis. Research Study PR 76 ioozo. Central Intelligence Agency, Office of Political Research. Washington D.C.

Miller A. H. ( 1979) 'Hostage negotiations and the concept of transference'. In: Alexander, Y., Carlton, D. and Wilkinson, P. (eds.), Terrorism: Theory and Practice. Boulder, Co.: Westview Press.

Sandler, T., Tschirhardt, J. and Cauley, J. (1983), 'A Theoretical Analysis of Transnational Terrorism', American Political Science Review, vol 77.

Sandler, Todd and Scott, John L. ( $\mathrm{r}^{8} 7$ ) 'Terrorist Success in Hostage Taking: an Empirical Study', Joumal of Confict Resolution, March.

Stohl, Michael (ed.) (1979) The Politics of Terrorism. New York and Basel: Dekker.

U.S. Central Intelligence Agency (1981) Patterns of Intemational Terrorism: 1980. Springfield, VA: National Technical Information Service.

Watson, Francis M. (1976) Political Terrorism: The Threat and the Response. Washington-New York: Robert B. Luce.

Wilkinson, Paul (1974) Political Terrorism. London: Macmillan.

Wilkinson P. (1977) Terrorism and the Liberal State. New York: Macmillan.

Wilkinson P. (1986) 'Trends in International Terrorism and the American Response'. In: Royal Institute of International Affairs (ed.), Terrorism and Intemational Order. London: Routledge \& Kegan Paul 